\title{
Implications of Politically Exposed Persons participation in 2015 Elections in Nigeria
}

\author{
Dr. R.O. Oji \\ Department of Political Science, Enugu State University, Enugu \\ Eme, Okechukwu I \\ Onyishi, Anthony 0 \\ Department of Public Administration and Local Government, University of Nigeria, Nsukka \\ okechukwunncnt@yahoo.com
}

\section{Doi:10.5901/mjss.2014.v5n27p207}

\section{Abstract}

In May 2007, a number of governors completed their eight-year term of office. Having lost the immunity conferred on them by Section 308 of the Constitution, the Economic and Financial Crimes Commission (EFCC) invited them for investigation on the basis of several petitions alleging diversion of public funds running to billions of naira. Some reported for interrogation while others sought interlocutory and perpetual injunctions restraining the EFCC from arresting, investigating or prosecuting them in any manner whatsoever and howsoever. Among those who were charged to court only two have been convicted and given light sentences. The majority of the defendants have continued to manipulate the criminal justice system to frustrate their trial. To the eternal shame of the country one of the ex-governors who got a clean bill of health by a Nigerian court was later convicted and jailed by a British court. Out of the two, who jumped bail in the United Kingdom, one is now a Senator of the Republic. Not unexpectedly, the Nigerian people have justifiably blamed lawyers and judges for frustrating the anti-graft agencies from successfully prosecuting politically exposed persons and other members of the ruling class accused of corrupt practices and money laundering. In this presentation we shall examine how the neo-colonial legal system is regularly exploited by senior lawyers in favour of rich and powerful criminal suspects to the detriment of accountability and transparency in the society. And the questions remain: Is there a way out of the woods? Can this trend change as Nigeria approaches 2015 Elections? What are the implications of this trend? Even the judiciary has not helped matters together with the agencies saddled with the responsibility of checkmating corruption and prosecuting corrupt individuals. These issues pose great dangers for 2015 Elections. This is because many among them are going to stand or sponsor cronies for 2015 Elections in order to protect their loots and still remain relevant in political matters in post 2015 Nigeria.

Keywords: Politically Exposed Persons, Corruption, Graft, Economic Crimes, vertical-horizontal accountability.

\section{Introduction}

Since the Independent National Electoral Commission (INEC) released the timetable for the 2015 and those of governorship elections in Ekiti and Osun States, the readiness or otherwise of the Commission to conduct the 2015 general elections has come into public discourse. It is against this background that the INEC Chairman, Prof. Attahiru Jega has been invited by certain organisations/groups among them is the media, which see the election as a determinant to the existence of the entity called Nigeria, to speak on what INEC is doing towards 2015 elections.

Prof. Jega explained these in detail, part of which was on the innovation the commission has put in place to ensure it has a credible voter register, which is very critical in having credible elections, Continuous Voter Registration (CVR) and other measures to secure the electoral materials and other fundamental changes aimed at reforming the electoral process. In a lecture, Building Credible Electoral Process for democratic Sustainability the Chairman explained that the immediate objective of his team on assumption of office in 2010 was to restore credibility to electoral process based on the fact that quality of Nigeria's elections was progressively declining, adding that out goal for 2015 is not just to make the elections much better than 2011, but also in compliance with global best standards.

Some of the electoral reform measures introduced by the commission prior to 2011 general elections which brought about the improvement in the election include but not limited to production of a new Biometric Register of voters, introduction of a remodified open ballot system, improved security features on sensitive electoral materials such as serial numbering and colour coding of ballot papers, result sheets as well as security coding of ballot boxes, enhanced voter 
education and citizens engagement, more transparent procedures on Election Day, including pasting of results at polling units and collation centre, and creation of the inter-agencies consultative committee on election security to ensure coordinated engagement of all security agencies during election periods.

Prof. Jega enumerated some of its plans and programme of activities to achieve its goal. These include among others a strategic plan (2012-2016), which is a detailed Election Project Plan (EPP), the implementation of which will ensure seamless execution of specific tasks leading to the 2015 elections, comprehensive re-organisation and restructuring of the commission consolidation and de-duplication of the biometric register of voters before 2015 elections and the commission will not use addendum register for elections again, issuance of chip-based permanent voters cards, which will be swiped with card readers in the 2015 elections to ensure 100 percent verification and authentication of voters a communication policy/strategy designed to improve both internal and external communication by the commission and an electoral risk management tool will be deployed ahead of the 2015 elections to enable the commission gather information about risk factors associated with elections.

However, INEC alone cannot bring about free, fair and peaceful election without the support of all other stakeholders. There are challenges ahead of the 2015 elections, which the chairman never pretended about as the spoke at the forum. The challenges, though not insurmountable are securities, funding attitude of the political class described as key challenge confronting the electoral system, which is of great concern to the commission. This is so because even if the management of elections meets the highest standards, as far as the contestants do not play by the rules, there is definitely going to be problems. Among these contestants that would constitute the biggest challenge to 2015 Elections at the Politically Exposed Persons.

In May 2007, a number of governors completed their eight-year term of office. Having lost the immunity conferred on them by Section 308 of the Constitution, the Economic and Financial Crimes Commission (EFCC) invited them for investigation on the basis of several petitions alleging diversion of public funds running to billions of naira. Some reported for interrogation while others sought interlocutory and perpetual injunctions restraining the EFCC from arresting, investigating or prosecuting them in any manner whatsoever and howsoever.

Corruption cases litter our courts. Former governors who are having their day in our courts include Ayo Fayose (Ekiti), Orji Kalu (Abia), Chimaroke Nnamani (Enugu), Sani Ahmed (Zamfara), Saminu Turaki (Jigawa), Rashidi Ladoja (Oyo), Joshua Dariye (Plateau), Jolly Nyame (Taraba), and Boni Haruna (Adamawa) to name a few. The Economic and Financial Crimes Commission (EFCC) has also arraigned former bank chiefs for alleged financial crimes, including the chief executives of the defunct Bank PHB Francis Atuche and Finbank, Okey Nwosu. Others are Mrs. Cecilia Ibru (Oceanic Bank); Mr. Sebastian Adigwe (Afribank); Bartholomew Ebong (Union Bank), and Dr. Erastus Akingbola (Intercontinental Bank).

Among those who were charged to court only two have been convicted and given light sentences. The majority of the defendants have continued to manipulate the criminal justice system to frustrate their trial. To the eternal shame of the country one of the ex-governors who got a clean bill of health by a Nigerian court was later convicted and jailed by a British court. Out of the two, who jumped bail in the United Kingdom, one is now a Senator of the Republic.

Combating corruption in Nigeria has been an uphill task. While many believe that the anti-graft war will remain rudderless until there is a strong commitment from the highest level of government, others argue that the courts have been the greatest $\operatorname{cog}$ in the wheel of the anti-graft war. Not unexpectedly, the Nigerian people have justifiably blamed lawyers and judges for frustrating the anti-graft agencies from successfully prosecuting politically exposed persons and other members of the ruling class accused of corrupt practices and money laundering. In this presentation we shall examine how the neo-colonial legal system is regularly exploited by senior lawyers in favour of rich and powerful criminal suspects to the detriment of accountability and transparency in the society and challenge they pose to 2015 Election.

\section{Clarification of Concepts: Politically Exposed Persons}

There is no internationally agreed-upon definition of politically exposed persons. As a result, understanding who these "customers" are and how far the definition of PEPs should stretch is a difficult and politically sensitive topic (UNDOC and World Bank, 2007:25).Standard setters generally agree that PEPs are individuals who are, or have been, entrusted with prominent public functions, such as Heads of State or government (World Bank, 2007:25). The standards setters and a considerable number of jurisdictions also expect financial institutions to treat prominent public official's family and close associated as PEPs (UNDOC and World Bank, 2007:25).Attempts to provide increased clarity to the definition have resulted in some standard setters limiting the scope of the PEP definition to exclude domestic PEPs, family members beyond immediate family, junior or middle ranking PEPs.

In some cases, countries have issued a limited list of positions that financial institutions are obliged to consider as 
politically exposed. Some of these restrictions may be designed to allow for greater efforts to be expended on more exposed PEPs (Limitations on Junior or middle - ranking).Flexibility on this issue also seems to make sense for each individual jurisdiction. At the same time, core definitions that are too restrictive (for example, including only immediate families and close associates) are likely to create loopholes, as evidenced on actual corruption cases (UNDOC and World Bank, 2007:25). Specifically, the ACAMS International Glossary of key Money Laundering Terms and Acronyms (2001), the Wolfsberg Global Anti-Money Laundering Guidelines for private Banking (2001) and Swiss Federal Banking Commission (2001) define politically exposed persons as "individuals holding or having held positions of public trust, such as government officials, senior executives of government corporations, as well as their Families and close associates" (Wolfsberg, 2001:2)

While there is no global definition of a PEP, the Financial Action Task Force (FATF) (2005) issued guidelines in which the term politically exposed Person was defined. The Revised Financial Action Task Force's (FATF) 40 Recommendations define PEPs as individuals who are or who have been entrusted with prominent public functions in a foreign country for example Head of State or of Government, senior politicians, judicial or military officials. This definition is not intended to cover middle ranking or more junior individuals in the foregoing categories. The FATF document also says that business relationships with family members or close associates of PEPs involve 'reputational risks similar to those of PEPs themselves.

The Wolfsbery Group (2008) World Compliance (2008) Don Jones (2010) and World Check (2010) add that the term should be understood to include persons whose current or former position can attract publicity beyond the borders of the country concerned and whose financial circumstances may be subjected to additional pubic interest. In specific cases, local factors in the country concerned, such as the political and social environment, should be considered when deciding whether a person falls within the definition.

UNCAC (20003), FATF and The Third European Union Directives have stretched the definition of PEPs. The former defines PEPs as individuals who are, or have been, entrusted with prominent public functions, and their family members and associates. The latter adds that they are natural persons who are or have been entrusted with prominent public functions and immediate family members, or person known to be close associates of such persons. The under listed examples are intended to serve as aids to interpretation:

1. Head of state government and cabinet ministers

2. Influential functionaries in nationalized industries and government administration;

3. Senior judges

4. Senior party functionaries;

5. Senior and /or influential officials, functionaries and military leaders and people with similar functions in international or supranational organizations;

6. Members of ruling royal families;

7. Senior and /or influential representatives of religions organizations (if these functions are connected with political, judicial, military or administrative responsibilities (Wolfsberg Group, 2008:1).

Through these definitions did not specifically separate foreign and domestic politically exposed persons but have identified guidelines, in which the term politically exposed persons was defined. The interpretation of each of these layers varies from one country to another. Some jurisdictions focused only on foreign political figures .Some countries limit the definition to the national level, some include regionally politically exposed persons. While there might be slight variation of the five layers above, the expectations of an organization doing business with politically exposed persons are universally similar.

The United Kingdom Money Laundry Regulations (2007) define PEP as a persons who is or has, at any time in the proceeding year entrusted with a prominent public function by a state other than the united kingdom, a (European) community institution or an international budget or a family member, known close association of such a person Section 312 of the USA Patriot Act, Foreign Corrupt Practices Act, United Nations Convention against corruption (2003) among others did not include middle ranking and junior individually in the categories in the above definitions. However, the term PEPs is not used in FinCen's regulation. According to FinCen's regulation, PEPs describes a person who has been entrusted with a prominent public function, or an individual who is closely related to such a person. The Canadian Antimoney Laundering Regulation shows a large degree of overlap with the PEP definitions used in most other countries of the world; and is also comparable to the "senior foreign political figure" as outlined in the USA patriot Act.

The Canadian Act definition is:

Is a person who or holds or has ever held one of the following positions in or behalf of a foreign state. The list includes:

a. Head of State or head of government 
b. Member of the executive council or government or member of a legislature;

c. Deputy minister or equivalent rank

d. Ambassador or attaché or counsellor of an ambassador

e. Military officer with a rank of General or above;

f. President of state owned company or a state owned bank;

g. Head of a government agency;

h. judge

i. Leader or president of a political party represented in a legislature; or

j. Holder of any prescribed office or position (Wikipedia, 2009:1)

This definition includes any prescribed family member of such a person. Although there is no global definition of PEP, most polities have based their definition on the FATF definition:

1. Current or former senior official in the executive, legislature, administrative, military or judicial branch of a foreign government (elected or not)

2. A senior official of a major foreign political party;

3. A senior executive of a foreign government owned commercial being a corporation, business or other entity formed by or for the benefit of any such individual

4. An immediate family member of such individual; meaning spouse, parents, siblings ,or children and spouse's parents or siblings

5. Any individual publicly known (or actually known by the relevant financial institution) to be close personal or professional associate.

The Wolfsberg Group (2008) PEPs definition applies to persons who perform important public functions for a state. This definition used by regulators or in governance is usually way general and leaves room for interpretations. For example, the Swiss Federal Banking Commission in its guidelines on money laundering uses the term "person occupying an important public function", the US interagency guidance uses senior foreign political figures" and the BIS paper customer due diligence for bank says "potentates" In real life, it may be difficult to identify someone as PEP; this designation is chiefly aimed at preventing those who have been in a position of authority from making use of their plundering of state funds. Some countries have passed laws aimed at preventing "capital fight", Nigeria for instance, prohibits its states Governors from holding bank account in other jurisdictions.

But the likelihood is that of someone has amassed funds illegally, they will somehow find a way or ways of transferring them out of their country ahead of their own fight: Perhaps even as school fees or pocket money" for a child. For our purpose, PEPs are individuals who are or have been entrusted with prominent public functions, including members of the executives legislature, judiciary, military administrative officers, appointed local and international officers representing their countries in domestic and international fora and celebrated political, banking and financial institutions and extra-ministerial appointees as well as members of their nuclear and extended families and close associates in a polity who are involved in grand corruption.

\section{PEP and 2015 Election: The Freed, the Suspended and the Convicted}

Sanusi Lamido Sanusi, the Former Governor of the Central Bank of Nigeria (CBN), has been tinkering with his monetary policy regime in recent times, most of which have been targeted at defending the naira. While price stability has also been the overriding interest of the governor, and has seen the CBN maintaining a tight monetary stance for almost two years, a bigger worry has been the value of the naira.

In order to maintain the exchange rate of the naira within a band of N150 - N160 to the US dollar, the CBN, last August, sterilised 50 per cent of public sector funds by raising the cash reserve requirement on funds belonging to the three tiers of government. The immediate impact of the policy was the spike in interest rates at the interbank market as well as rates charged by banks on commercial loans. But the primary objective of the central bank, which was to further tighten liquidity in order to stem speculative attacks on the naira, still fell short of expectations.

Exacerbated by the inconsequential impact the sterlisation of public sector funds had on the value of the naira, the central bank adopted a number of new measures, one of which was the revocation of licences of 20 bureau de change operators. Others included the reinstatement of the Retail Dutch Auction System as the CBN window through which banks could procure foreign exchange on behalf of their customers; increased the annual limit on the naira credit card from $\$ 40,000$ to $\$ 150,000$; and banned the importation of foreign currency, stipulating that foreign exchange transfers into Nigerians must be paid in naira at the prevailing interbank rate. In defence of the measures, Sanusi said Nigeria had overtaken Russia as the largest importer of foreign currency, insisting that no country in the world pays its citizens in 
foreign currency for transfers into their economies. However, what Sanusi refused to voice was his concern that the demand for foreign currency by politically exposed persons had reached alarming proportions as the 2015 elections draw near.

With every election cycle since 1999, the central bank has been forced to anticipate the rising demand for foreign currency by politicians who need to spend obscene amounts of money during electioneering. But as 2015 looms, the introduction of the cashless policy has combined with the inconvenience of carrying large amounts of local cash, to make foreign currency more attractive to politicians who have to either throw away cash to "win" the hearts and minds of the electorate, party officials and electoral officials or stash away their ill-gotten loot in smaller, more manageable bills. Add to this the spike in demand for foreign currency among foreign and institutional investors who would prefer to hold their cash in dollars with the ever-rising political uncertainty that every election cycle brings.

That is the real crux of the matter which the central bank has very little capacity to control, because despite all the measures, the naira keeps depreciating in the inter-bank and parallel markets, while foreign exchange reserves accretion continues to head south. With the release of N1.2 trillion to the three tiers of government last week, following the Federation Account Allocation Committee (FAAC) meeting, the demand pressure for the US dollar is expected to be rapacious in the weeks ahead. Of major concern to Sanusi is the fact that Nigeria is an import-dependent economy. Other than a few essential food crops, we literally import everything we need in the country. This means that when there is a speculative attack on the local currency, it inevitably results in import-induced inflation, a scenario that gives Sanusi sleepless nights. But while Sanusi has recorded some success at keeping the rate of inflation in check and has even managed to keep it at single-digit for most of this year, he has had little success at curbing the demand for foreign currency and its adverse effect on foreign reserves accretion.

Unbridled crude oil theft and vandalism have eroded whatever gains the country could have enjoyed from crude oil selling at an average of $\$ 105$ per barrel for much of this year. The result is that earnings from crude oil, which account for almost 90 per cent of foreign exchange receipts, have fallen short of expectations and reserves accretion has taken a back seat.

Global Financial Integrity (GFI) (2012), reports that crime, corruption, and tax evasion cost the developing world $\$ 858.8$ billion in 2010, just below the all-time high of $\$ 871.3$ billion set in 2008-the year preceding the global financial crisis. The findings are part of a new study released by the Washington-based research and advocacy organization.

The report, "Illicit Financial Flows from Developing Countries: 2001-2010," is GFI's annual update on the amount of money flowing out of developing economies via crime, corruption and tax evasion, and it is the first of GFl's reports to include data for the year 2010. Co-authored by GFI Lead Economist Dev Kar and GFI Economist Sarah Freitas, the study is the first by GFI to incorporate a new, more conservative, estimate of illicit financial flows, facilitating comparisons with previous estimates from GFI updates.

Astronomical sums of dirty money continue to flow out of the developing world and into offshore tax havens and developed country banks," said GFI Director Raymond Baker. "Regardless of the methodology, it's clear: developing economies are hemorrhaging more and more money at a time when rich and poor nations alike are struggling to spur economic growth. This report should be a wake-up call to world leaders that more must be done to address these harmful outflows."

The $\$ 858.8$ billion of illicit outflows lost in 2010 is a significant up tick from 2009, which saw developing countries lose $\$ 776.0$ billion under the new methodology. The study estimates the developing world lost a total of $\$ 5.86$ trillion over the decade spanning 2001 through 2010. "This has very big consequences for developing economies," explained Ms. Freitas, a co-author of the report. "Poor countries lost nearly a trillion dollars that could have been used to invest in healthcare, education, and infrastructure. It's nearly a trillion dollars that could have been used to pull people out of poverty and save lives." Dr. Kar and Ms. Freitas' research tracks the amount of illegal capital flowing out of 150 different developing countries over the 10-year period from 2001 through 2010, and it ranks the countries by magnitude of illicit outflows.

Irrespective of the data presented above as it cancers Nigeria, President Goodluck Jonathan likes to impress it on Nigerians that he is winning the war against the cancer of corruption. But going by the realities of local and global barometres, corruption is defying all therapeutic treatments in Nigeria. For instance, on Monday, 28 January, 2014, Nigeria was further highlighted on the globe as the sickliest joker of Africa. On that day Yakubu Yusuf, a billionaire pension thief, becomes a classic exemplar of that joke that the justice system has turned into. An Abuja High Court on that day sentenced the former head of the Police Pension Board to a two-year jail term for pleading guilty to the embezzlement of N23.3 billion. Yusuf will also forfeit property valued at N325 million. But the pension thief would not be going to the prison after all. He got an option of N750000 to stave off a life behind the bars. For many anti-corruption campaigners, the Yakubu conviction yields nothing but a painful antithesis: the speed with which the nation's justice 
system clamp petty thieves to a jail term and the other 'speed' by which elite criminals get a reprieve for building the nation in ways less than patriotic.

It is worthy to note that before Yusuf's case, it was the granting of amnesty to his former boss, Diepreye Alamieyeseigha, former governor of Bayelsa state. Most currently are the cases of the current PDP National Chairman Adamu Mauzu and Boni Haruna the minister for youth development. For instance, the Coalition against Corrupt Leaders (CACOL) had faulted the nomination of the former governor of Adamawa State, Mr. Boni Haruna, in the ministerial list of President Goodluck Jonathan. The President had sent a list of eleven ministerial nominees to the Senate for screening and confirmation.

Speaking in a press statement to African Examiner Chairman of the Coalition, Comrade Debo Adeniran, condemned the choice of Boni Haruna and averred that his nomination makes a mess of the anti-corruption war of the federal government. Adeniran, mentioned that it is unfortunate that despite the barrage of allegations against Boni Haruna, Mr. President could still nominate him for ministerial appointment. According to him:

This confirmed our fear that President Jonathan himself is neck-deep in corruption, hence he wouldn't have find it easy to romance people of questionable character so openly. He quarried, How could the President that claimed he's working assiduously to rid the country of corruption nominate an accused into his cabinet? Is it because there's dearth of people with impeccable pedigree that the President is left with no other choice than Boni Haruna? This same Boni Haruna, was arraigned on a 28 count charges of fraud and embezzlement of public fund during his administration as governor of Adamawa State between 1999 and 2007. He was arraigned alongside one Mohammed Inuwa Bassi, a former Minority Leader in the Adamawa State House of Assembly, John Babani Elias, his aide and Al-Akim Investment Nigeria Limited. They were first arraigned in 2008. Also, Haruna was alleged to have on or about the 13th day of November, 2002 at Yola fraudulently uttered a Guaranty Trust Bank Plc Cheque no.0348501 dated 13/11/2002 in the sum of N 10,000,000.00 drawn on account number no 3613406139110 to Guaranty Trust Bank Plc, operated by him in the name of Mohammed Inuwa Bassi, with intent that the said cheque may be acted as genuine and thereby committed an offence contrary to section 3 (2) (a) of Miscellaneous offences Act, Cap 410 Laws of the Federation of Nigeria 1990 as amended by the Tribunals ( certain consequential Amendments, etc) Decree no 62 of 1999 and punishable under Section 3 (2) of the same Act. In the same vein, Mr. Boni Haruna, was also alleged to have on or about the 12th day of March, 2003, while he was still a governor, fraudulently uttered a Guaranty Trust Bank PIc, cheque no. 3049628 dated 12/3/2003 in the sum of N16,125,000.00 drawn on account number no, 3613406139110 to Guaranty Trust Bank Plc, operated by him, in the name of Mohammed Inuwa Bassi with intent that the said cheque may be acted upon as genuine (Adelowokan, 2014:14).

The Coalition against Corrupt Leaders (CACOL) however said it is shameful that a 'fraudster' could be nominated as a Minister of the Federal Republic of Nigeria. The anti-corruption crusade therefore called on the Senate to reject any ministerial nominee of questionable records, most especially those indicted or facing corruption charges with the anti-graft agencies. This effort did not yield the desired result.

First it was James Onanefe Ibori, a 'sacred cow', who bagged a 13 years sentence for money laundering charges in far away London, after initially slipping through the greased fingers of legal perverts in the Economic and Financial Crimes Commission and their cronies in the Nigerian judiciary. The other sacred cows-like Orji Uzor Kalu; Saminu Turaki; Chimaroke Nnamani; Joshua Dariye etc- whose affidavits of corrupt enrichment and abuse of office have been in court for more than five years now, still roam the corridors of power unfettered. It is estimated that about N8 trillion of Nigeria's common wealth derived mainly from its main source of revenue oil, has been frittered away by people in government in the past 13 years. This stupendous volume of unchecked stealing by public servants and political office holders has contributed significantly in impoverishing a larger percentage of the population (Eme, 2012).

Despite the over abundance of human and material resources majority of Nigerians continue to live below breadline. In all these the apex leadership of the ruling class undoubtedly complicit in corruption has done little or nothing to stem the tide. But for few high profile convictions, majority of the people allegedly involved in the lootings still walk free and most times in corridors of power. Nigerian Orient News investigations revealed that no sector of the Nigerian social life has been left unconquered by these marauders.

While it has been difficult to prosecute these powerful individuals locally and bring them to book, most of the cases that have international links have been completely dispensed with and justice seen to have been obtained. Notable is the case of Atiku Abubakar, former vice president of Nigeria and later presidential aspirant under the ruling People's Democratic Party. Atiku Abubakar was indicted in a high profile bribery scandal involving foreign companies one of which is Siemens AG of Germany. The indictment of Atiku Abubakar was an aftermath of an investigation by the United States Senate Permanent Sub Committee on Investigations (Committee on Homeland and Security and Government Affairs). Titled "Abubakar Case Study :Using Offshore Companies To Bring Suspect Funds Into the United States" one Miss 
Jennifer Douglas Abubakar a U.S citizen and fourth wife of Atiku Abubakar was said to have helped her husband between 2000 and 2008 to bring in over $\$ 40 \mathrm{~m}$ of suspect funds into the United States .

According to the reports most of the funds were transferred by little known corporations primarily LetsGo Ltd Inc. and Sima Holdings Ltd, some of the payments being bribe payments from Siemens AG, a German corporation and which case Atiku Abubakar has not answered in any court in Nigeria. In the same report it was indicated that Ms Jennifer Atiku used most of the money placed into her accounts to live a lavish lifestyle in the US paying credit card bills and house hold expenses in the range of $\$ 9000$ to $\$ 10000$ per month including legal and accounting bills. One of such bills the report revealed was the payment of $\$ 14 \mathrm{~m}$ and another $\$ 2.4 \mathrm{~m}$ transferred through Guernsy Trust Co. Ltd. and LetsGo Ltd. as consulting fees to American University in the United States from the American University of Nigeria established in 2003 and closely associated with Atiku Abubakar.

In a damning note the report said:

Over the years questions have been asked about the source of Mr. Abubakar's wealth. He spent over twenty years in Nigerian Custom Service and then worked ten years in the private sector before serving as vice president of Nigeria from 1999 to 2007. While vice president of Nigeria Mr. Abubakar was the subject of corruption allegations relating to Nigerian Petroleum Technology Development Funds (Anudu, 2013:13).

Interestingly the co-accused in the bribery scandal Siemens AG of Germany admitted engaging in widespread bribery payments in Nigeria, pleaded guilty to criminal violations, settled civil violations of the US Foreign Corrupt Practices Act and agreed to pay over \$1.6m USD in criminal and civil violations. While Atiku Abubakar still walks free and even aspired to the highest office in Nigeria, despite all these allegations and subsequent indictment overseas, James Onanefe Ibori, former governor of oil rich Delta state in Nigeria was not very lucky. After several attempts by the Nigerian anti corruption agency, Economic and Financial Crimes Commission (EFCC) to prosecute and nail him of numerous corruption charges failed, it was the Metropolitan Police in the U.K that finally jailed Ibori after he admitted to have embezzled about $£ 157 \mathrm{~m}$ belonging to Delta state government. In a curious twist of judicial maneuvering, James Ibori had been acquitted and discharged of all 143-count charges preferred against him by EFCC, while all his cohorts including wife, mistress, house help and lawyer had all been jailed in the UK for same offenses.

In a near similar case, the Metropolitan Police of United Kingdom in 2005 allegedly found $£ 1 \mathrm{~m}$ cash in the London home of Diepreye Alamieyeseigha, former governor of Bayelsa state home state of current Nigerian president, Good luck Jonathan. The Metropolitan Police was to later find a total of $1.8 \mathrm{~m}$ in cash and bank account also acknowledging that he has properties in London valued at $£ 10 \mathrm{~m}$. But before the United Kingdom authorities could set measures to bring him to justice in the UK for money laundering offenses, Alamieyeseigha jumped bail in London allegedly disguising himself as a woman and returned to Nigeria where he was eventually impeached, prosecuted and received a light jail sentence while still retaining a larger chunk of his loot. Only recently did the United States take over his assets worth a meager \$401.931 (Mordi, 2010).

The Nigerian Police, the body created by an Act of Parliament to maintain law and order which includes apprehending thieves of any category has also seen itself enmeshed in rather mind boggling corruption cases. Former Inspector General of Police Tafa Balogun was in 2005 arraigned before a Federal High court in Abuja on charges of corruptly enriching himself to the tune of N16b. Even though he was convicted to six months imprisonment part of which he served in the National Hospital Abuja as a patient, Nigerians were yet served with another dose of corruption comedy when in 2008 the House of Representatives Committee Chairman on Police Affairs, Abdul Ahmed Ningi told Nigerians that the loot recovered from Tafa Balogun could not be accounted for by then Inspector General of Police Mike Okiro and Farida Waziri the then boss of the EFC, the supposed corruption fighter. While these two top crime busters were said not to be able to account for about N6b of loot money recovered from their former colleague Tafa Balogun, Nigerian Orient News investigations revealed that the said properties were allegedly sold to private individuals at give away prices (Anudu, 2013).

In 2009, the National Coordinator of the Police Equipment Foundation Mr. .Kenny Martins and others named Ibrahim Dumuje, Joni Icheka and Cosmos Okpara were alleged to have embezzled N7.7b belonging to the Foundation. After all manipulations to evade justice even when Kenny Martins had also been involved in another scandal of obtaining fraudulently the sum of $\$ 97.5 \mathrm{M}$ on behalf of the Federal Government of Nigeria from Calvary Security Corporations in United States, a Federal High Court sitting in Abuja in a land mark judgment in June 2012 agreed that Kenny Martins and his cohorts have a case to answer in the alleged scam (Eme, 2009).

Currently the EFCC is prosecuting several people due to their unholy involvement in Pensions Administrations. In a gullible display of insatiable appetite to steal, six staffers of the Police Pension Office were arraigned before a Federal 
High Court in Abuja for stealing N32.8b belonging to the Police Pensions Board. Little wonder that police men who risk their lives in their service years protecting lives and property of fellow citizens end up in abject penury after service. In like manner the EFCC has confiscated properties of one Dr Sani Tiedi Shuaibu a former director, Pension Administration in the office of the Secretary to the Federation who is standing trial over a N4.5b pension scam (Anudu, 2013).

In January 2012, the EFCC told an Abuja High Court that Mr. Dimeji Bankole former Speaker House of Representative and his deputy Usman Nafada have a case to answer in the N38bfraud and criminal breach of trust instituted against them shortly after leaving office. Despite discharging and acquitting the duo on the 17-count charge brought against them the anti graft agency still insists that they are culpable of the offence (Eme, 2012).

The culture of corruption has become so pervasive in Nigeria that it has not only permeated the fabric of our society but has become a tradition. Just recently in April 2012, the EFCC arraigned three staff of the Federal Service Commission before an Abuja High Court a on 12-count charge bordering on forgery and fraudulent conversion of N109m just as it also arraigned the Chairman of the Ondo State Oil Producing Area Development Commission OSOPADEC Mr. Adebowale Henry Ajimuda and four others on 13 count charge of embezzling N540m belonging to Ondo State. When Hon. Ndudi Elumelu the then House of Representatives, committee chairman on Power and Steel ,embarked on a thorough investigation of the power sector after Hon.Dimeji Bankole ,then Speaker of the House of Representatives said that close to $\$ 16 \mathrm{~b}$ had been spent on power sector without tangible results, little did Hon Elumelu know that he had undertaken a journey aimed at self destruction. The committee after discovering huge scams in the power sector suddenly got tangled with allegations of bribery to the tune of $\mathrm{N} 100 \mathrm{~m}$. The accusers alleged that Hon. Ndudi Elumelu had collected money ostensibly to exonerate some powerful individuals who had been implicated in the power sector scam. Up until this moment nothing has been heard or said about the \$16b (Eme and Chukwuma, 2011).

An attempt by the Federal Government of Nigeria to remove subsidy on Premium Motor Spirit (PMS) popularly known as fuel opened a Pandora's Box which stories are still developing till today. On the insistence and prompting of Nigerians that corruption and fuel had been subsidized all along, the House of Representatives set up an Ad Hoc committee to look into alleged irregularities in the fuel subsidy regime. The committee after its investigation discovered that N1.4 trillion had been unlawfully paid out to the treasury looters. This particular fraud is said to be the most monumental in Nigeria and in Africa considering that it is close to half the annual budget of Nigeria and that of about seven West African countries put together.

Few months after the submission of the report of the Panel which included recommendations for appropriate sanctions to culprits, Nigerians were yet treated to another drama when Mr. Femi Otedola whose company Zenon Oil had been fingered as one of the beneficiaries of the loot, came out to say that the chairman of the Ad Hoc Committee Hon. Farouk Lawan had solicited for $\$ 3 \mathrm{~m}$ out of which $\$ 620,000$ had been paid out to enable Hon Farouk Lawan remove Zenon Oil from any complicity in the scam. This ugly development is believed by Nigerians as another calculated attempt to hoodwink them and divert attention from the real issue of the N1.4trillion loot, while the recommendations for appropriate sanctions would be swept under the carpet and go the way of similar previous exercises (Eme, 2012).

Apart from the much publicized case of Diepreye Alamieyeseigha and James Onanefe Ibori, two former governors of oil rich Bayelsa and Delta states who converted their states treasuries to personal estates, many other governors who presided over their states as Imperial Lords are currently under trials for corruptly enriching themselves while in office. On April 27, 2012 a Court of Appeal sitting in Abuja affirmed that the former governor of Abia state Orji Uzor Kalu had questions to answer in the case involving Abia state funds totaling N5b.The said funds were allegedly transferred from Abia State account in Manny Bank now Fidelity bank to Orji Uzor Kalu's SLOK Nig. Ltd. account in Inland Bank.

On 27 July 2007, former Governor Orji Uzor Kalu of Abia State appeared before an Abuja High court on a 107count charge of money laundering, official corruption and criminal diversion of public funds in excess of N5 billion. Kalu pleaded not guilty to the charges and his counsel asked the court for bail. But Justice Binta Murtala Nyako decided otherwise. She ordered his detention at Kuje Prison in Abuja while she fixes the date for the argument for bail. Maybe the Honourable Justice should have told that to the marines. Kalu was on the streets four days later (Eme and Chukwuma, 2011).

In similar circumstances Governors Christopher Alao Akala and Jolly Nyame of Oyo and Taraba states are standing trials on charges which border on corrupt enrichment while in office. Both governors are accused of stealing monies totaling N3.8b. While Alao Akala is said to have used his ill gotten wealth to acquire properties in Nigeria and London, Jolly Nyame also is said to have used up monies from state coffers to acquire properties in Nigeria and abroad. Jolly Nyame was squarely indicted when a former accountant of the state Rural Electrification Board told an Abuja High Court that he withdrew N282m from the account of the Board which he personally handed over to the governor. Going by EFCC records Governors Danjuma Goje and Akwe Doma are both standing trials for financial crimes committed while in office. Cumulatively both governors are said to have made away with N76b of their states' money. Governors Chimaroke 
Nnamani of Enugu state, Rasheed Ladoja of Oyo state, Olusegun Agagu of Ondo and Gbenga Daniels of Ogun states are all standing trial in one court or the other for corruptly enriching themselves while in office. According to EFCC records these four former governors while in office and in connivance with civil servants under them stole a staggering N46b from their states. As some of these governors are out of office and government battling to save their heads from these criminal charges, many others accused of similar offences are still in government carrying on with the business of the day, living very large in the midst of people they pauperized (Eme,2012).

Former governor of Plateau state Joshua Chibi Dariye, now Senator of the Federal Republic of Nigeria, jumped bail in London after the Nigerian government had filed a case against him in London, where he had run to having evaded arrest in Nigeria. In the said case, the Nigerian government alleged that Mr Dariye had used fake name of Ebenezer Ratman to open accounts in former All States Trust Bank and siphoned N1.3b of Plateau state money. In July 2007, Dariye was arraigned before an Abuja High Court on a 23-count charge involving the sum of N700 million. He pleaded not guilty to all the charges and got a bail. And in the usual subversive antics of former governors haunted by corruption trials, Dariye challenged the jurisdiction of the court to try him. He contended that the alleged offence committed by him took place in Plateau State. He also contended that the funds involved belonged to Plateau State and argued that his trial ought to take place in the state, not in Abuja.

His case file now fossilizes in the court. And Dariye, the accused, is now a distinguished senator of the Federal Republic of Nigeria. Former governor of Kwara state now Senator Bukola Saraki , the man who at the onset insisted on the floor of the Senate that there were irregularities in fuel subsidy management was recently quizzed by the Special Fraud Unit of the Nigerian Police on allegations that he was complicit in a N21m loan, just as the former governor of Kaduna state now Senator Ahmed Markafi is alleged to have defrauded the state with the appellation 'Liberal State' of $\mathrm{N} 1.3 \mathrm{~b}$.

In the same vein the former governor of Jigawa State, Senator Samina Turaki is allegedly not able to render accounts of N36b of his state money. Turaki, too, was docked on a 32-count charge involving stealing about N36 billion from his state over an eight-year period. After a brief detention, Turaki was granted bail in the sum of N100 million on 27 July 2007. Apparently to enable him hibernate in the hallowed chamber also as a Senator. And like Dariye, he too successfully secured the transfer of his trial to his home state where the files now rest in peace.

Former Enugu State governor, Chimaroke Nnamani, who spent four years in the Senate after leaving office in 2007, is one huge beneficiary of this Judicial laxities. He was arraigned before a Lagos Federal High Court on a 105count charge for allegedly stealing the sum of N5.3 billion. He pleaded not guilty and also got a bail. Ditto for Nyame. He was docked on a 41-count charge in July 2007. He was alleged to have embezzled the sum of N1.3 billion. Part of the allegations against Nyame was that he collected N180 million from USAB International Nigeria Limited. The money was a kick-back from a N250 million contract awarded to the company for the supply of stationery to the state government between January and February 2005. Nyame, in his statement, said he approved the said contract and promised to refund whatever bribe was given to him. He said in his statement: "On the issue of my share of N180 million, I must confess; I must contact the government officials, who allegedly gave me the money. Whatever is my share, I will refund"(Eme,2012). Nyame also had a comic twist. He moaned that the amount attributed to him by the EFCC was far above what he took. Meaning he owns up to the allegations against him.

In corporate Nigeria, there's also batch of mega-rich captains that have escaped justice, after haemorrhaging the banking industry: Cecilia Ibru, former MD, Oceanic Bank; Erastus Akingbola, former MD, Intercontinental Bank PLC; Batholomew Ebong, former MD, Union Bank; Francis Atuche, former MD, Bank PHB; Sebastine Adigwe, former MD, Afribank PLC; and Chief Osa Osunde, chairman, Afribank.

A number of indicted lawmakers also found a solace in the rotten chamber of justice. Senator Nicholas Ugbane, Hon. Ndudi Elumelu and others in the N5.2b Rural Electricity Agency contract case, bought their way out of the scam. The former Speaker Dimeji Bankole and his deputy Usman Nafada also got away with a N40 billion Scandal. Farouk Lawan, too, has been hibernating in court since he got smeared in the subsidy probe report. One of the big catch of the oil scandal--Femi Otedola, owner of Zenon Group—remains a fixture in Jonathan's itinerary (Falana,2014).

In all these screw-ups, there appears a beaten path to swinging justice: buying time to end up in a plea bargain. For many of the perennial cases, Lamorde explained to the Senate committee, the EFCC has gone to Supreme Court twice -- on mere interlocutory applications. "They will file this, the judge will overrule them, they will go to Court of Appeal and lose there, but they will still go to Supreme Court. At the Supreme Court, the case would then be referred to the trial judge for continuation, then a fresh application will follow suit. "We know how long it takes for a trial to go to Court of Appeal and get listed, then go to the Supreme Court to get it listed and decided upon (Eme and Oko,2011).

It is painful to note that the lawyers involved in the prosecution and defense of the cases referred to in this paper are Senior Advocates of Nigeria. The Nigerian Bar Association owes the legal profession a duty by calling lawyers who 
frustrate the prosecution of corruption cases to order. Trial courts are also enjoined to report such lawyers to the Disciplinary Committee of the NBA for appropriate actions.

For attitude, many believe Jonathan's a wimp. And that has brought his administration's approach to corruption under attacks by his critics. The Patriot, a group of senior citizens led by Prof. Ben Nwabueze, said the president's loose handling of high-profile corruption cases is responsible for the "failure to punish appropriately and promptly" the few politicians prosecuted for corruption.

Lai Mohammed, APC national publicity secretary, for instance, would describe it as "an amazing lack of political will". Debo Adeniran, chairman Coalition against Corrupt Leaders, would brand the ministries, departments, and agencies championing the crusade against corruption "a bunch of unserious lot". This name calling, galled as it is, seems to have some rhymes and reasons. Since ex-President Olusegun Obasanjo teed-off the anti-corruption campaign in 2001, 1500 cases have been prosecuted, 12 years after. As at the administration of the Farida Waziri, the second chairman of the Economic and Financial Crimes Commission, the arrowhead of the campaign, 400 convictions were recorded, out of the 600 cases concluded. Most of these are petty cases, including advanced-fees fraudsters and other cybercrimes. The heat was fully on initially, under the commission's pioneer chairman, Nuhu Ribadu. He actually grossed in over 700 of these cases, including those of 19 governors in office between 1999 and 2006. About $\$ 6.5$ billion, Farida said, was recovered in 2010 while around $\mathrm{N} 1$ trillion worth of asset was temporarily forfeited. The total number of top-flight cases stood at 50 two years ago.

But Ribadu was eased out in 2007, and the EFCC began to lose steam. The ousting of Farida, for nonperformance, in 2011 brought in Ibrahim Lamorde. Critics, however, believe the fight is icing over faster than ever before. Under this government, Dino Melaye, the executive director the Anti-Corruption Network, was quoted in a newspaper report, corruption has graduated from the stealing of millions to trillions. Other civil rights leaders are equally spurting out figures, angrily. "In the last two years, an estimated N5 trillion has been stolen by our government officials," said Joe-Okei Odumakin, president, Campaign for Democracy. Odumakin's guesstimate would have included the over N1 trillion sunk in the oil subsidy scandal, the Malabu oil scam, the pension heist, and the Nigerian Security Printing and Minting N2.1 billion misappropriation. There, on the other hand, is a cabinet-load of probe reports gathering dust in Aso Rock. No ass-kicking yet.

As these billions of naira evaporate, the EFCC and its sister Independent Corrupt Practice and other Related Offences Commission (ICPC)are just faffing around. The commissions have admitted their failures. The fact on the ground is that no case has been concluded," the EFCC boss told the Senate Committee on Narcotics, Drugs, and Financial Crimes in November. But Lamorde, like his master, wouldn't take responsibility. The non-conclusion of many of the cases, especially of the politically exposed persons', according to the EFCC boss, is inevitable. "These are people who have the resources to drag these cases indefinitely and perpetually," he told the committee. Actually, there are cases that have been dangling since 2006. Plus many of the over 200 Larmode has brought to law.

Dragging the cases, with pedestrian applications, is effectively the specialty of the corrupt lawyers - the bigwigs among them. So Lamorde will like the Nigeria Bar Association to take the knock,too. As expected, the NBA has fired back in the blame game.

According to Okey Wali, NBA's president, "They are their own problem," Besides the investigative incompetency of the anti-graft agencies noted by the NBA, the judiciary too, Wali said, is part of the problem. "What are the judges doing with these frivolous applications brought by the lawyers" (Anudu,2013) he asked.

The buck has been on the judges table for long, really. Mike Aondoakaa, a former attorney-general of the federation stuck out like a sore thumb in the late President Umar Yar' Adua's administration. Aondakaa moved artfully against the prosecution of the 19 governors caught in Ribadu's dragnet then. He particularly wagered his wig on James Ibori, the former governor of Delta, serving terms in a UK prison for being guilty of corruption. The AG went as far as the Southwark, in London, to defend Ibori. Mohammed Adoke, the current AG, also scotched the EFCC by snatching away its prosecutorial powers; that his office alone wields such powers. Adoke's declaration didn't just surprised Nigerians; it made them further believe the judiciary is out to help corruption fester.

Now, the public perception says Itse Sagay, law professor and constitutional lawyer, is that judgements are purchasable and judges have no integrity. Court registers across the federation groan with names of such big buyers. These are mainly well-heeled bureaucrats, party heavyweights, and their cronies.

\section{Implications of PEPs for 2015 Election}

Nigeria has been classified as a corrupt country with a poor governance record, while discrimination against women, the less privileged, lesbian, gay, bisexual and transgender (LGBT) people is common place. 
This is coming on the heels of the disclosure by the Director-General, Bureau of Public Procurement (BPP), Mr. Emeka Ezeh that N95.79 billion was saved through the implementation of due diligence in public contracting and procurement in the fourth quarter of last year.

United States Secretary of State, John Kerry made the corruption allegations on Thursday in his well- advertised "Country Reports on Human Rights Practices" which he presented at the Press Briefing Room of the State Department in Washington.

Kerry warned that the US was not acting out of arrogance but to plug the pitfalls arising from its experiment at home and help the human race against making avoidable mistakes.

"Even as we come together today to issue a report on other nations, we hold ourselves to a high standard and we expect accountability here at home too. And we know that we're not perfect. We don't speak with any arrogance whatsoever, but with a concern for the human condition," the Secretary of State said.

This year's report, he stressed, "is especially timely coming on the heels of one of the most momentous years in the struggle for greater rights and freedoms in modern history."

Confirming an earlier report by THISDAY that the US would give Nigeria a minus in its country report on gay rights and extra-judicial killings, Kerry said: "From Nigeria to Russia to Iran, indeed in some 80 countries the world over, LGBT communities face discriminatory laws and practices that attack their basic human dignity and undermine their safety.

"We are seeing new laws like the Anti-Homosexuality Bill enacted by Uganda and signed into law by President Yoweri Museveni earlier this week, which not only makes criminals of people for who they are, but punishes those who defend the human rights that are our universal birthright," Kerry said

The more than 20,000 words document touched on virtually every aspect of Nigeria's constitution while most of the time scoring the country poorly for its performance, taking a huge swipe on the anti-corruption agencies-the EFCC, ICPC and the Police.

The report which ranked the EFCC's commitment to the anti-corruption war higher than that of the ICPC said Ibrahim Lamorde's efforts at prosecuting offenders were frustrated along the way.

"The anticorruption efforts of the Independent Corrupt Practices Commission (ICPC) and EFCC remained largely ineffectual. The ICPC holds broad authorities to prosecute all forms of corruption, whereas the EFCC is tasked with handling only financial crimes. Despite this wider mandate, the ICPC had achieved only 68 convictions since its inauguration in 2000."

Repeating its earlier disapproval of President Goodluck Jonathan's pardon of former Bayelsa State governor Diepreye Alamieyeseigha, it noted that Police corruption remained rampant. "In January, the police released a new code of conduct, which includes provisions on officer integrity. The police did not report any enforcement actions related to the code of conduct."

It condemned the impunity with which officials of the Nigerian government allegedly frequently engaged in corrupt practices at all levels with the police and security forces factored in, wondering why the constitution provides immunity from civil and criminal prosecution for the president, vice president, governors, and deputy governors while in office.

On the issue of declaration of assets, the country report did not spare President Goodluck Jonathan for not disclosing his assets.

Financial disclosure law, it said, requires public officials, including the president, vice president, governors, deputy governors, cabinet ministers, and legislators (at both federal and state levels), to declare their assets to the Code of Conduct Bureau before assuming and after leaving office with violators risking prosecution. However, it lamented, cases rarely came to conclusion.

"The president had not published information on his assets as of year's end," insisting the law required declaration of assets but not publication of the report.

The report listed an array of cases left hanging including that of former Bayelsa State governor Timipre Sylva for allegedly laundering over N5 billion; the yet to be tried John Yakubu Yusuf who is alleged to have embezzled N2 billion from the Police Pension Fund; Farouk Lawan who was also alleged to have solicited bribe from Zenon boss Femi Otedola.

Lamorde, according to the report, seemed to have been constrained "by the fact he is being tele-guided by those that put him in office, on who to arrest and prosecute while his efforts at trying 12 prominent public officials met a brick wall with several frustrating setbacks during the year."

The report continued: "Despite the arrest of several high-ranking officials by the EFCC, including Dimeji Bankole and Hassan Lawal, who have been left off the hook, allegations continued that agency investigations targeted individuals who had fallen out of favour with the government, while those who were in favour continued their activities with impunity."

In conclusion, Kerry summarised once more the reason for his country report exercise: "This is about 
accountability. It's about ending impunity. And it's about a fight that has gone on for centuries, as long as human beings have been able to think and write and speak and act on their own.

Apart from being his political benefactor, what could be Mr. President's other over-riding reasons for granting pardon to Alamieyeseigha? One could just be possible political relevance of the politician. Alamieyeseigha called himself the "Governor General of the ljaw" when he was governor of the ljaw heartland; so he is seen as a milestone in the political and economic struggle of the ljaw. He had a great rapport with the militants that have been granted amnesty and have found sudden wealth. In addition, politically he is still seen as a strong voice for the ljaw nation. With Edwin Clark over 80 years old, there appears a vacuum that Alamieyeseigha who 'produced' the first president for the South-south could fill in the political leadership of the ljaw. Each time he had tried to be relevant at the national stage, the 'ex-convict' tag had been a restraining factor. With this stain now officially removed, nothing stops him from going to the Senate in 2015 to represent his people.

Although Mr. President has had his way; however, there may be heavy price to pay for it, nationally and internationally. For instance, whatever pretence Jonathan's government made about fighting corruption might have been erased with this act. If he has the right feedback from the streets, Jonathan should have known that Nigerian feel his government is paying lip service to the anti-corruption crusade. He just handed the skeptics the needed confirmation. Under his watch, one of the greatest looting of the national treasury was carried out under the petroleum subsidy regime where an unprecedented amount of over N2.17 trillion, more than the whole capital budget of 2012, was reported stolen. After three independent investigations and another by the EFCC, only a handful of the alleged culprits are in court while the major beneficiaries are still enjoying government patronage. Even at that, the cases in court may not lead to proper punishment of crime due to political interference.

Politically, it has ominous implications for Jonathan's re-election in 2015. His popularity is at very low ebb on the streets. For a candidate who was more popular than his party in 2011, his slide down the prism of public conscience was rather too steep. He may have squandered his political capital too fast. The civil society was his partner in 2010/2011. They were at the barricades fighting for the doctrine of necessity, which made him acting president. They upheld and fought for his right to contest the presidential election in 2011 when the North canvassed a northern successor to Yar'Adua in line with PDP's zoning principle. They mobilized Nigerians to vote for him during the presidential election. During the post-election riots against his election in some northern states, the civil society stood behind him. The only thing they wanted from Jonathan was good governance and war against corruption. Since then, no politically exposed person has been convicted of corruption and jailed as expected by the civil society; rather those convicted by regimes before him are being granted pardon. This has further alienated civil society from power.

Internationally, the action further dented Nigeria's image. The charges against Alamieyeseigha were investigated by the Metropolitan Police and other UK anti-fraud agencies, interpol and Nigeria's EFCC and ICPC; his state pardon belittles Nigeria before the comity of civilized nations. At home, it demoralized the anti-corruption agencies. Some of their staff, who is officially not allowed to speak to the press, told the magazine that it means they are wasting their time indicting more suspects. One of the fallouts might include operatives collecting money of source during investigation and letting the suspects go. Many critics are wondering why Jonathan chose to grant the controversial pardon now when his government is being assessed for the halfway mark. An insider told the magazine it was the best time for it. "It was either now or after 2015; it will be suicide to do it close to the election," he explained in confidence. The thinking is that some other good act would mitigate the anger caused by the pardon before the 2015 election. Jonathan tried a similar gamble when he attempted to propose an amendment to the constitution to prescribe a single term of six or seven years for the president/vice president and governors/deputy governors immediately after his victory at the 2011 polls. It ended in a deadly row, which the Presidency did not exit without a bloodied nose. The strategy too was based on Machiavelli's prescription that princes should carry out unpopular but necessary reforms and actions at the beginning of their regimes as these would be mitigated by later acts of charity.

So what do Nigerians think about the pardon? Plenty! The President trended very low across the major social networks like Facebook and Twitter. The overwhelming perception was that Jonathan had let the people down.

Ribadu, former chairman of EFCC, who convicted Alamieyseigha, described it as "a sad development" and "a sore point for the anti-corruption as." Femi falana, SAN, said it "should not be viewed by Nigerians in isolation but in the context of the atmosphere of impunity in the land." Anthony Sani, spokesman for Arewa Consultative Forum, ACF, described it as a setback for the war against corruption and an indication that Jonathan is not serious about fighting corruption. However, Doyin Okupe, senior special assistant to the president on public affairs, defended the President last Wednesday on Channels Television breakfast show. "The relationship between President Jonathan and Alamieyeseigha is not something that is hidden, neither is it something that is immoral. It was a pardon that was granted by the highest institution in the country. It is not every decision that a parent takes that is palatable to the children. But later, you find out 
that you have taken the right decision as a parent".

He wondered what the fuss is all about. "The council is empowered to grant the pardon. What is all this noise about Alamieyeseigha and the pardon? Is it because it is him? Is it because he is a Niger Deltan? Is it because of his closeness to Jonathan? Even in our laws, though I am not a lawyer, there are certain offences that you commit and after 10 years, you receive presidential pardon. There is a Yoruba saying, 'you asked a thief to run, he runs. You asked him to drop what he has stolen, he did. What else do you want from him?"

Diepreye Alamieyeseigha is a happy man, and this is because the stigma of an ex-convict which, like a leper, he as carried for years has been yanked off him. This is courtesy members of the Nigeria Council of state. Alamieyeseigha was Baylsa state Governor and President Goodluck Jonathan his Deputy. However, when Alamieyeseigha was impeached in December 2005 on account of corruption, Jonathan stepped into his shoes as Governor.

\section{Recommendations}

On the basis of the foregoing analysis, we propose the following suggestions, which, could help reposition the commission and make the current attempt to curb political corruption more effective:

(a) A restructuring of Anti-corruption agencies and INEC's leadership, with a view to bringing on board men and women of high moral standing known for their personal commitments to the crusade against corruption and electoral frud will be required to restore their credibility. In order to win public confidence, support and participation, which are necessary conditions for any successful struggle against corruption, the appointment of the top echelon of the commissions would need to be opened up to some form of public participation. It will be helpful in this regard if the government, involve at least a significant section of the civil society, including opposition parties.

(b) The Acts should be revisited, with a view to effecting the changes that will empower them to:

1. Monitor potential sources of corruption and investigate individuals on grounds of reasonable suspicion, as against the present practice, where the commission can not probe anyone, irrespective of the amount of evidence available to it, except upon the receipt of a petition.

2. Probe cases of corruption irrespective of the date of the offence. One way of doing this, is to empower the commission to prosecute such individuals where strong grounds exist in its opinion, but on the basis of previously existing laws.

3. Receive sufficient independent funding, to lessen its dependence on the whims and caprices of the executive and legislature. It could draw its funding from a Consolidated Revenue Fund, as applicable to the judiciary.

(c) A radical and comprehensive reform of Nigeria's institutions for the administration of criminal justice. Experience has shown that the police and the Judiciary are key institutions which require urgent reforms, in the battle against corruption and other crimes.

(d) Anti-corruption agencies officials need to acquaint themselves very well with the provisions of the Act, to avoid running foci of the law. An impartial and non-political body, charged with the responsibility of supervising its operations, to ensure that its operations are done within the limit of its enabling statute will be useful.

(e) There is need to review and strengthen other anti-corruption and election institutions, as the responsibility of rooting out all forms of corruption can not be reasonably left to one institution, in a society where corruption so ubiquitous. The Office of the Auditor General and the Code of Conduct Bureau are relevant institutions and finally

(f) There is need to sensitise and mobilize the civil society to assume its role of watchdog. The political class can be forced by a well mobilized civil society, to demonstrate absolute commitment to transparency and accountability and the required political will to lead the struggle, by shunning corruption and leading by example.

Similarly, the restriction on daily outbound foreign currency transfers should be relaxed by the Central Bank. At the moment, the CBN imposes a daily limit of $\$ 10,000$, but such rules have outlived their uses if a commercial bank has done a proper Know Your Customer (KYC) for the account holder and duly reports it. Besides, it is such arcane rules that encourage the importation of foreign currency.

Realistically, there is an urgent need for a review of CBN's foreign exchange rules. As Sarah Alade prepares to step in few months from now, she should use the time to align the rules with modern practices and make them easy to operate. Most transactions should be made eligible and in reasonable amounts to curb the demand for cash in foreign currency denominations. But more importantly, CBN's foreign exchange monitoring function needs to be upgraded to 
anticipate the ebb and flow of the market and improve its capacity to track legitimate and illegitimate transactions.

\section{Conclusion}

Nigerian President Goodluck Jonathan wants the world to believe he and his government are serious about ending corruption. But two recent events have sent out the opposite message. As President Jonathan handed out awards to celebrate Nigeria's centenary, there was a collective leap of eyebrows when people learnt that former President Sani Abacha was on the list. Many wondered why a military dictator who had plundered the nation was being celebrated. As if people needed reminding, during that same week the United States announced that it was freezing $\$ 458 \mathrm{~m}(£ 275 \mathrm{~m})$ that had been stashed away in foreign bank accounts - part of at least \$3bn that Abacha is believed to have looted during the 1990s. A presidential spokesman tried to calm things down by stating that the centenary award was "not a test of sainthood" but was for Abacha's "contribution to keeping the country together".

The renowned Nigerian writer Wole Soyinka was so incensed he rejected his own award, describing the former president as "a murderer and thief of no redeeming quality" and "a man who placed this nation under siege during an unrelenting reign of terror".

The second event came after outspoken Central Bank governor Lamido Sanusi had accused the state oil company, Nigerian National Petroleum Company (NNPC), of failing to account for $\$ 20 \mathrm{bn}$ in oil revenues. Some critics accused Mr Sanusi of playing politics but when he was then accused himself of financial recklessness and was suspended; it was widely seen as a move to silence a whistleblower who was causing the government embarrassment. It was by no means the first time that corruption in the NNPC was being highlighted. But this is on another level. The allegation is that more than $\$ 1$ bn was disappearing every month over a 19 -month period.

Mr Sanusi said he was speaking out because of the potential impact on the entire economy. Mr Sanusi told the BBC on one of his last days in his Central Bank office, "Oil prices are over $\$ 110$ [per barrel] and we have a relatively healthy current account surplus yet we are facing exchange rate pressures, which is the last thing we should face at this point in time," (). He said he hoped a parliamentary investigation would also find out why the country's Excess Crude Account had fallen from $\$ 11.5 b n$ to under $\$ 2.5 b n$ in a year - arguing that Nigeria's savings are a vital buffer against any drop in the global oil price and without this "rainy day" account, the economy is vulnerable and exposed.

In view of the above, this article has reviewed Nigeria's recent attempts at fighting corruption, focusing specifically on one of the principal anti-corruption institutions, the ICPC, which as we have seen has failed to curb corruption especially among the political class. Rather than secure the conviction of these corrupt officials, the reason for why it was established, ICPC have become politicised and neck-deep in damaging controversies, losing its credibility in the process. So that it is now seen by some as a mere instrument for witch-hunting political enemies. Its dismal performance has been partly due to its own many internal contradictions and administrative problems, but more fundamentally, to systemic factors outside its control, i.e. the prevailing néo-patrimonial orientation of the political class who politicised the exercise and used the deficiencies in the legal system to frustrate attempts to combat corruption in Nigeria. This has destroyed public confidence in the ongoing efforts to fight corruption, and eroded the legitimacy of the principal agency for the war against graft.

These developments are not completely unexpected, given that, at birth, ICPC and indeed its enabling status, did not receive a very warm reception from all sections of the political class. State Governments and the federal legislature had right from the beginning been very suspicious of its powers, which explain why it took the lawmaking body one full year to pass the Bill in to law, after injecting the clause that the President and his Vice along with the governors and their deputy should not be immune from similar probe. Several state governments also registered their opposition to the anticorruption law which they said was a violation of the constitution. These challenges foretold the kind of opposition which ICPC is to confront.

\section{References}

Adebayo F. \& Adewuyi, O. ( 2011), Ibori's Case Puts the Judiciary On the Spot, Tell Magazine February 14, 2011

Adelowokan, K. (2014), "Ministerial List: Coalition against Corruption Leaders Faults Boni Haruna's Nomination; African Examiner, Monday, January 27, p. 14

Adekeye, F. (2009) "In the Bosom of Fraud Nigerian Government Keeps Quite over the fate of Public Officials Allegedly Bribed by Foreign Companies Now facing trial abroad". Tell No. 8. Feb. 23 P. 32.

Agomuo, Z. (2012), "The Waziri-Lamorde Complaints Any Substance? Business Day, Thursday 29, November, P. 44.

Aiyetan, D. (2009) "A Spark of Sleaze: Some very Drastic Action by the Presidency is expected to follow the Unearthing by investigators of the Alleged looting of Public Funds at Nigerian Electricity Regulatory Commission". Tell No 8 Feb 23 Pp. 24-25. 
Andrei, S. \& Vishny, R.W. ( 1998 ), The Grabbing Hand: Government Pathologies and their Cures, Washington DC: World Bank

Anudu, O. (2013), "How Nigeria lost N8 Trillion to Corruption is 13 years", Orient Energy Review, July 25.

Asobie, H.A. (2012a), "The Corruption Perception Index 2012, (1)" The Guardian, Thursday, 27, P. 62.

Asobie, H.A. (2012b), "The Corruption Perception Index 2012, (2)" The Guardian, Friday 28, P. 61.

Aziken, E \& Agande (2012), "As Federal Government Dismisses TI rating," Vanguard, December 6,P. 8.

BBC (2014), "Corruption on another level", - BBC Assesses Jonathan's 'Anti-corruption' Crusade", March 13, 2014

Committee on Banking Supervision (2001), Customers Due Diligence for Banks, Based: Bank for International Settlement, Basel: Swiss Bank.

Eme O.I (2012), "Politically Exposed Persons and April 2011General Elections in Nigeria: Challenges before Anti-Corruption Agencies," paper read at the International Political Science Association Conference held at Madrid between 7 and 11 June, 2012.

Eme, O.I et al. (2012), EFCC and Politically Exposed Politicians in Post 2011 Elections: an Analysis of Governors who lost Elections, Arabian Journal of Business and Management Review (OMAN Chapter) ,Vol. 1, No. 8, (March) Pp. 74-98

Eme, O.I et al. (2009) "Corruption in Nigeria: The National Assembly Experience, 199-2006", in Tony Edoh and Terhemba William (eds), Democracy, Leadership and Accountability in Post-Colonial Africa: Challenges and Possibilities, Makurdi: Aboki Publishers.

Eme, O.I. and Okoh, C.I. (2011), "The Role of EFCC in Combating Political Corruption," Oman Chapter of Arabian Journal of Business and Management, Vol.1. No 3 (October), Pp 45-68.

Eme, O.I.(2010) "Corruption in Nigerian Government Institutions: A case of Police Equipment Fund, Journal of Liberal Studies, University of Nigeria, Nsukka, Pp. 440-458.

Falana, F. (2014), "How Courts Frustrate Corruption Cases", TheNation, Thursday, April 24, Pp. 40-41.

Federal Republic of Nigeria (1999), Constitution of the Federal Republic of Nigeria, Lagos: Federal Government Press.

Global Programme Against Corruption (2001), "Empowering the Victims of Corruption Go.

Greenberg, T.S., Gray, L., Schantz, D., Latham, M. and Gardner, C. (2009) "Stolen Asset IRIS, (1996), 'Governance and the Economy in Africa: Tools for Analysis and Reform of Corruption', Centre for Institutional Reform and the Informal Sector (IRIS), University of Maryland.

Kar, D. and Freitas, S. (2012), Illicit Financial Flows from Development Countries: 2001-2010, Washington, DC: GFI.

Maku, Okupe Blame Nigeria's Corruption Index on negative media", The Sun on Saturday, December 6, P. 7.

Mordi, R. (2010), "Early Cases of Corruption" TELL June 7, p.18.

Nwaogwugw, D. I. (2013), "Te Problem with the Naira", Sunday This Day, Sunday, October 13, p. 76

Ogundare, G. (2013), "A Nation's Cancer", National Standard, Friday, March 1, Pp. 8-14.

Okpaga A., Ugwu S. C., Onyishi, A.O. \& Eme, O.I. (2012), EFCC and Politically Exposed Politicians in Post 2011 Elections: An Analysis of Governors who lost Elections, Oman chapter of Arabian Journal of Business and Management Review (AJBMR) Vol.1, No 7, February Edition, Pp.74-98.

Olaleye, O. Akosile, A. et al (2012), "Transparency International Ranks Nigeria 35th most Corrupt Nation", December 6, Saturday This Day, Pp. 8-9.

Owete, F. (2014), "Falana Slams Nigeria's Senior Lawyers, Judges, accuses them of Frustrating corruption trials", Premium Times, Friday, April 18, P.

Sunday Sun Editorial (2012), "Nigeria's Dismal Corruption Ranking”, Sunday Sun, December 7, P. 15.

Tullock, G., 1996. 'Corruption Theory and Practice', Contemporary Economic Policy, 14(3):6-13, Washington DC: World Bank

UNDOC and the World Bank (2007), Stolen Asset Recovery (SAR), Initiative: Challenges,

Wikipedia (2012), Overview of Corruption Perception Index (2012).

Wikipedia Free Encyclopedia (2009), "Politically Exposed Persons"

Wolfsberg Group (2005), Wolf bergs Anti-Money Laundering, Principles on Private Banking,

Wolfsberg Group (2008) "Frequently Asked Question on Politically Exposed Persons"

World Bank, (1997a), Report of the Corruption Action Plan Working Group (CAPWG) - Country and International Strategies, OPC Review Draft, May.

World Bank, (1997b), Helping Countries Combat Corruption: The Role of the World Bank, Washington, DC: World Bank.

World Bank (2007), Politically Exposed Persons - A Policy Paper on Strengthening Preventive Measures, Washington DC: World Bank. 